\title{
SOME EFFECTS ON BLOOD COAGULATION OF ERYTHROCYTES AND OTHER CELLS
}

\author{
BY \\ J. R. O'BRIEN \\ From the Central Laboratory, Portsmouth, and Isle of Wight Area Pathological Service, \\ Milton Road, Portsmouth
}

(RECEIVED FOR PUBLICATION APRIL 21, 1958)

The activity of intact cells or of extracts from cells may be studied in blood coagulation systems to elucidate the problems of coagulation or to investigate the properties of cells and their extracts. The present report is concerned primarily with the latter objective.

Since the beginning of this century aqueous extracts of cells have been known to accelerate clotting. In $1916 \mathrm{McLean}$ prepared a protein-free accelerator from brain by extraction with lipid solvents. Crosbie and Scarborough (1941) reported that the clotting time of plasma when Russell viper venom was used was accelerated by the haemolysis of red cells. They suggested that this acceleration might be due to a highly active phospholipid. Quick, Georgatsos, and Hussey (1954) also reported the coagulant activity of red cell haemolysates, and Hussey and Kaser (1956) prepared an active phospholipid extract of red cell stroma and called it erythrocytin.

If platelets are removed by centrifugation from citrated plasma, on recalcification this plasma clots badly ; if platelets are added to such plasma, the clotting process reverts to normal. Using platelet-poor plasma as a substrate, substances of known chemical structure or tissue extracts or intact cells may be added in order to see what will correct the defect as completely as platelets themselves. Material which can substitute for platelets will be called "active" and that which has no effect will be called " inactive." A chemical substance or tissue extract which exhibits full activity is almost certain to contain cephalin-like molecules, and these must be either free or " available" at the surface of a larger molecule (O'Brien, 1958). It is still possible that there are chemical configurations other than the cephalins that could mimic the action of platelets, but the definition of "activity" remains and is a useful concept.

This report is not immediately concerned with the thromboplastic substance found, for example, in a saline extract of brain, which has properties quite different from those of platelet-lipid, but such a brain extract contains active lipids (McLean, 1916) and these are "available" for tests able to detect platelet-like activity. In brain extracts the active lipid is combined with a protein and both components seem to play a part in determining its thromboplastic power (Mills, 1921 ; Chargaff, Ziff, and Cohen, 1940). In studying some tissue extracts advantage was taken of the species specificity (Trevan and Macfarlane, 1936) of the brain-like activity to exclude it. Many human tissue extracts possess this activity in varying degree when tested in human plasma. Guinea-pig tissue extracts, when tested in human plasma, exhibit platelet-like activity but no brainlike activity.

\section{Experimental Observations}

Methods.-The methods of Biggs and Macfarlane (1957) were used throughout, and the tests employed, which are all very sensitive to platelet deficiency, were as follows: the plasma clotting time, the prothrombin consumption index, the thrombin generation test, the thromboplastin generation test, and the "stypven" time, which is especially sensitive to the addition of small quantities of active lipid (O'Brien, 1956). A suspension of "asolectin," a phospholipid extract of soya beans, $1 \mathrm{mg} . / \mathrm{ml}$. saline, was frequently used as an easily controlled substitute for platelets.

Red Cells.-One volume of fresh, intact, washed. human red cells in saline was added to platelet-poor plasma and the mixture was tested in all the abovementioned tests; it was found that this addition did not improve the performance when compared with the saline control. Red cells may, therefore, be called inactive. A sample of these washed red cells was haemolysed by the addition of distilled water and the red cell ghosts were washed 10 times in water by repeated centrifugation at 4,000 r.p.m. for 15 minutes. The resulting particulate grey deposit, free of haemoglobin, was regularly found to be active in these tests. Particulate material after haemolysis by freezing and by ultrasonic agitation, after haemolysis by digitonin, 
Clostridium welchii, $\alpha$ toxin, and other haemolytic agents, was more difficult to wash by centrifugation, but these unwashed, haemoglobin-containing haemolysates were also fully active in all tests.

Ghost red cells were prepared by the addition of $1 \mathrm{ml}$. of water to $1 \mathrm{ml}$. of packed washed red cells. The ghost red cells were pleomorphic but were usually pale biconcave discs, and they were always active. If the ghost red cells were centrifuged and resuspended in saline they again became inactive, and the sequence of activation and inactivation by suspending the haemolysed ghost red cells successively in water or saline could be repeated. The total ionic strength in any clotting mixture was inevitably lowered when red cell ghosts in water were added. The activity of isolated phospholipids was barely affected by such a change (Table I).

TABLE I

STYPVEN CLOTTING TIME OF RED CELLS VARIOUSLY TREATED

\begin{tabular}{|c|c|c|}
\hline \multicolumn{2}{|c|}{ Test Substance } & $\begin{array}{c}\text { Clotting } \\
\text { Time (sec.) }\end{array}$ \\
\hline $\begin{array}{l}\text { Red cells in saline + plasma } \\
\text { Red cell ghosts in water , } \\
\text { Red cell ghosts in saline ,, } \\
\text { Asolectin in water , } \\
\text { Asolectin in saline }\end{array}$ & $\begin{array}{l}\text { ven }+ \text { calcium } \\
,, \\
,, \\
,, \\
,,\end{array}$ & $\begin{array}{l}24 \\
12 \\
20 \\
15 \\
17\end{array}$ \\
\hline
\end{tabular}

One volume of each material was used. Red cell ghosts in saline were prepared from the red cell ghosts in water by centrifugation, removal of the water, and the addition of an equal volume of saline.

Asolectin = a commercial mixture of active phospholipids, $1 \mathrm{mg} . / \mathrm{ml}$.

Stypven = Russell viper venom, $1: 10,000$ in water.

Calcium $=$ calcium chloride, $0 \cdot 025 \mathrm{M}$.

Other Cells. - It has already been reported that the stypven time of citrated whole blood is similar to that of platelet-poor plasma (O'Brien, 1956). Thus, intact platelets and white cells are inactive. The inactivity of intact platelets could not be investigated further, because in all other clotting tests the platelets break up in the early stages of coagulation. Live, washed HeLa* cells (a tissue culture explant from a human carcinoma of the cervix) and live, washed human sperms were shown to be inactive. No other live cells have been studied free from contamination with disrupted cells.

White cells (largely freed of platelets), platelets (largely freed of white cells), HeLa cells, and sperms were all killed and/or fragmented by freezing or boiling or ultrasonic agitation. The resulting suspensions always showed activity in whichever tests were used. The Hela cells sometimes showed slight brain thromboplastic activity. About $1 \mathrm{~g}$. of fresh guineapig lung, liver, muscle, brain, and fat was separately finely sliced and washed till grossly free from red cells. Each tissue was then ground up in $3 \mathrm{ml}$. of saline in a mortar. The saline extracts of all these organs were highly active.

${ }^{*}$ Dr. L. A. Hatch brought the HeLa cells of the BW line from the Virus Reference Laboratory, Colindale, to Portsmouth. Grown in lactalbumen Hanks solution with added human, horse, and calf serum, they were suspended by mechanical scraping.
Table II summarizes two typical sets of results. It will be seen that intact red cells were inactive throughout, and that live HeLa cells and sperms were almost completely inactive. When the extracts of guinea-pig tissues were added to guinea-pig plasma all the extracts (including human brain) had some

TABLE II

THE PLATELET-LIKE ACTIVITY OF CELLS AND CELL EXTRACTS IN CLOTTING TESTS

\begin{tabular}{|c|c|c|c|c|c|}
\hline Test Substance & $\begin{array}{c}\text { Guinea- } \\
\text { pig } \\
\text { Plasma } \\
+ \\
\text { Calcium }\end{array}$ & $\begin{array}{c}\text { Human } \\
\text { Plasma } \\
+ \\
\text { Calcium }\end{array}$ & $\begin{array}{c}\text { Human } \\
\text { Plasma } \\
+ \\
\text { Stypven } \\
+ \\
\text { Calcium }\end{array}$ & $\begin{array}{c}\text { Throm- } \\
\text { bin Gen- } \\
\text { eration } \\
\text { in } \\
\text { Human } \\
\text { Plasma }\end{array}$ & $\begin{array}{c}\text { Throm- } \\
\text { boplastin } \\
\text { Genera- } \\
\text { tion't }\end{array}$ \\
\hline $\begin{array}{ll}\text { Saline } & \ldots \\
\text { Asolectin .. } & \ldots \\
\text { Human intact } & \\
\text { R.B.C.s } & \ldots \\
\text { Human R.B.C.s } & \\
\text { fragmented } & \ldots \\
\text { Guinea-pig fat } & \\
\text { extract } & \ldots \\
\text { Guinea-pig liver } & \\
\text { extract } & \ldots \\
\begin{array}{l}\text { Guinea-pig lung } \\
\text { extract }\end{array} & \ldots \\
\text { Guinea-pig muscle } \\
\text { extract } \\
\begin{array}{l}\text { Guinea-pig brain } \\
\text { extract }\end{array} \\
\text { Human brain extract }\end{array}$ & $\begin{array}{l}42 \\
26\end{array}$ & $\begin{array}{r}230 \\
90 \\
235 \\
120\end{array}$ & $\begin{array}{l}22 \\
9 \cdot 5\end{array}$ & $\begin{array}{l}87 \\
12 \\
88 \\
11 \cdot 5\end{array}$ & \\
\hline 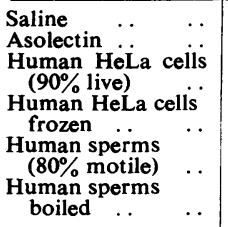 & & $\begin{array}{r}125 \\
45 \\
60 \\
45 \\
165\end{array}$ & $\begin{array}{c}23 \\
7 \cdot 5 \\
19 \\
12 \\
20\end{array}$ & $\begin{array}{r}125 \\
12 \\
120 \\
9 \\
120\end{array}$ & $\begin{array}{r}27 \\
7\end{array}$ \\
\hline
\end{tabular}

One volume of the test substance in saline was added to 1 vol. of plasma with or without 1 vol. of "stypven" as indicated, and the plasma with or in seconds are recorded in the first three columns. cloting times in seconds are recorded in the in seconds reported is that of the shortest fibrinogen
The time * The time in seconds reported is that of the
clotting time of any of the sub-sample tubes.

t This test is run normally, but the test substance was substituted for platelets. The shortest clotting time in seconds of any of the plasma sub-tubes is recorded.

thromboplastic activity, since all the clotting times were shorter than that caused by the addition of asolectin. But when added to human plasma they all accelerated the clotting time to about that caused by the addition of asolectin, a finding consonant with platelet-like activity. Under these conditions only human brain extract showed the typical thromboplastic activity. When the guinea-pig extracts were added to a mixture of human plasma and "stypven" the marked platelet-like activity was evident. All cell extracts showed marked activity in the thrombin generation test. In the thromboplastin generation test, damaged HeLa cells and sperms were active.

\section{Conclusions}

It seems probable that all human cells when alive and intact are inactive in all clotting systems, an observation known for many years (see, for 
example, Lister, 1863). The guinea-pig extracts were probably slightly contaminated with red cells and platelets, but the HeLa cells and sperms could not have been contaminated; it may be concluded that on death or disruption of all the cell types so far tested a considerable degree of platelet-like activity becomes manifest. Thus many cells are similar to platelets in exhibiting platelet-like activity on disruption. The unique property of platelets seems to be their ability under appropriate circumstances to release this activity into the blood stream.

The platelet-like activity of dead tissue cells may be related to the intercellular coagulation seen in infected tissues. In these circumstances plasma diffuses into the intercellular spaces. The damaged tissue cells, even if they do not possess brain-like thromboplastic properties, are now shown to possess platelet-like activity. Thus they may facilitate extravascular coagulation by virtue of this property. The platelet-like activity of the haemolysed red cells may be responsible for the thromboses in sickle cell anaemia and for the afibrinogenaemia following massive haemolysis due to an incompatible blood transfusion.

The red cell membrane is known to contain phospholipids, including cephalins, which on extraction exhibit platelet-like coagulant activity. Such activity is absent in intact red cells, is present in haemolysed red cell ghosts in water, and is again absent in red cell ghosts resuspended in saline. This suggests that in the first and last situations the cephalin molecules are so orientated that they are "unavailable" to clotting tests, but that in red cell ghosts suspended in water the cephalin molecules are differently, and reversibly, orientated. Evidence has already been presented (O'Brien, 1958) which suggests that cephalin molecules may be orientated in two ways in a protein molecule. Thus in some lipoprotein molecules the cephalin molecules are "available" to accelerate coagulation tests, and in other lipoproteins they are "unavailable."

The present findings combined with those of other workers suggest that three properties of cell membranes may be interrelated. These properties are osmotic activity, stickiness, and clotting activity. Teorell (1952) has shown that in red cell ghosts resuspended in saline the osmotic gradient is re-established. Bangham and Hancock (1955) have shown that dead sperms stick to glass beads but live sperms do not. It will be seen from Table III that, in all the situations studied, osmotic activity is associated with an absence of stickiness
TABLE III

POSSIBLE RELATIONSHIP OF SOME PROPERTIES OF CELL MEMBRANES UNDER DIFFERENT CONDITIONS

\begin{tabular}{|c|c|c|c|}
\hline & $\begin{array}{c}\text { Good } \\
\text { Osmometer } \\
\text { (Physio- } \\
\text { logically } \\
\text { Intact) }\end{array}$ & $\begin{array}{c}\text { “ Sticky" } \\
\text { Cell } \\
\text { Surface }\end{array}$ & $\begin{array}{c}\text { Activity in } \\
\text { Clotting } \\
\text { Systems } \\
\text { (" Available } \\
\text { Cephalins") }\end{array}$ \\
\hline 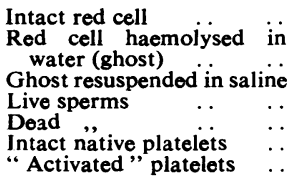 & $\begin{array}{l}\text { Present } \\
\text { Absent } \\
\text { Present } \\
\text { ? Äbsent } \\
\text { ? Present } \\
\text { ? }\end{array}$ & $\begin{array}{l}\text { Absent } \\
\stackrel{?}{?} \\
\text { Absent } \\
\text { Present } \\
\text { Absent } \\
\text { Present }\end{array}$ & $\begin{array}{l}\text { Absent } \\
\text { Present } \\
\text { Absent } \\
\text { Present } \\
\text { Absent } \\
\text { Present }\end{array}$ \\
\hline
\end{tabular}

and with an absence of coagulant activity. The reverse is also true: a damaged osmotically inactive membrane is sticky and exhibits coagulant activity. If these three properties of membranes are truely interrelated it is possible that the osmotic properties and the stickiness of the cell as well as the coagulant activity of the cell are all related to the orientation of the cephalin molecules at the surface.

\section{Summary}

Intact human red cells are inactive in blood coagulation tests. Red cell ghosts in water and washed particulate matter from the fragmented red cell membranes exhibit activity similar to platelet lipoid, and may therefore have "active" cephalin molecules suitably orientated at the surface. Red cell ghosts suspended in saline again become inactive. All other live intact cells are probably inactive. Fragmented, all cells examined have shown platelet-like activity. Some implications of these observations relating to the properties of the cell membrane are discussed.

This work was carried out during the tenure of a grant from the Medical Research Council, which I gratefully acknowledge. I also wish to thank Mrs. J. M. Cheaier, A.I.M.L.T., for technical assistance.

\section{REFERENCES}

Bangham, A. D., and Hancock, J. L. (1955). Nature (Lond.), $176,656$. Biggs, R., and Macfarlane, R. G. (1957). Human Blood Coagulation and its Disorders, 2nd ed. Blackwell, Oxford.

Chargaff, E., Ziff, M., and Cohen, S. S. (1940). J. biol. Chem., 136, 257.

Crosbie, A., and Scarborough, H. (1941). Brit. med. J., 1, 268

Hussey, C. V., and Kaser, M. M. (1956). Fed. Proc., 15, 279.

Lister, J. (1863). Lancet, 2, 179.

McLean, J. (1916). Amer.J. Physiol., 41, 250.

Mills, C. A. (1921). J. biol. Chem., 46, 135.

O'Brien, J. R. (1956). Lancet, 2, 232.

(1958). Nature (Lond.), 181, 420.

Quick, A. J., Georgatsos, J. G., and Hussey, C. V. (1954). Amer. J. med. Sci., 228, 207.

Teorell, T. (1952). J. gen. Physiol., 35, 669.

Trevan, J. W., and Macfarlane, R. G. (1936). Unpublished data quoted by Biggs, R., and Macfarlane, R. G. (1957). 